\title{
Den 'rådne banan' er human kapital - en analyse af kommunernes brug af uddannelse i beskæftigelsesindsatsen
}

\author{
Mads Peter Klindt \& Rasmus Ravn
}

Siden midten af 1990'erne er brugen af ordincer uddannelse i beskceftigelsesindsatsen for de forsikrede ledige faldet moerkbart. Udviklingen blev forstorket efter arbejdsformidlingssystemets nedloeggelse og oprettelsen af kommunale jobcentre i 2009. Imidlertid er der store forskelle mellem kommunerne. I artiklen undersøger vi hvilke faktorer, der har betydning for omfanget af kommunernes brug af uddannelse. Med afscet i litteraturen formuleres tre hypoteser, og efterfølgende analyseres et datascet konstrueret på baggrund af Jobindsats.dk. Analysen viser blandt andet, at uddannelsesaktivering gennemsnitligt set fylder mere i røde kommuner end blå. Desuden er uddannelse mere udbredt i de nord- og midtjyske kommuner end på Sjoelland. Endelig viser analysen, at syv af kommunerne i topti ligger i boeltet fra Vestjylland over Thy til Vendsyssel - den såkaldt 'rådne banan'. Vi diskuterer i den forbindelse, om det er fraflytning og mangel på arbejdskraft, der har forårsaget human kapital-strategiens revival i denne del af Udkantsdanmark.

Nøgleord: Aktiv arbejdsmarkedspolitik, aktivering, uddannelse, forsikrede ledige, lineær regression.

\section{Indledning}

I 2019 er det 25 år siden, den aktive arbejdsmarkedspolitik for alvor fik sit gennembrud i Danmark. Skiftet fra passiv til aktiv arbejdsmarkedspolitik var ikke noget isoleret dansk fænomen men en del af en international workfare-bølge, hvor arbejdsløses ret til sociale velfærdsydelser blev beskåret og gjort betinget af deltagelse i aktivering. Mens de angelsaksiske lande, Tyskland og Holland valgte en stærkt jobfokuseret tilgang til aktivering med vægt på at styrke lediges inci- tamenter til at søge arbejde (den såkaldte work first-strategi), blev Danmark imidlertid eksponent for en anden tilgang - human kapital-strategien, hvor det i højere grad er styrkelsen af arbejdsstyrkens kompetencer, der er i centrum for indsatsen (Torfing, 2004).

I 2000'erne blev arbejdsmarkedspolitikken omdøbt til beskæftigelsespolitik og fik gradvist et mere snævert fokus, der primært handlede om at bringe ledige ud af offentlig forsørgelse og tilbage på arbejdsmarkedet hurtigst muligt. Brugen af uddannelse og op- 
kvalificering faldt, imens virksomhedsrettede indsatser og samtaler med fokus på lediges jobsøgning blev opprioriteret. Udviklingen blev især forstærket efter 2008, hvor den statslige arbejdsformidling (AF) blev nedlagt og erstattet af kommunale jobcentre (Jørgensen \& Jørgensen, 2016). Med dagpengeforkortelsen fra 2010 medtaget i ligningen kan man dermed argumentere for, at Danmark i 2000'erne gradvist forlod den human kapital-strategi, vi slog ind på tilbage i starten af 1990'erne. Dansk beskæftigelsespolitik var blevet konvergent med den europæiske workfare mainstream.

En ny reform af beskæftigelsesområdet, der trådte i kraft 1 . januar 2015, har dog åbnet muligheden for, at ledige igen kan få et uddannelsesløft inden for rammerne af dagpengesystemet. Der er både muligheder for korte erhvervsfaglige forløb og for at løfte ufaglærte til faglært niveau. Forsyning af kvalificeret arbejdskraft til virksomhederne er ligeledes kommet på dagsordenen (Regeringen, 2014). Brugen af uddannelse er dog fortsat begrænset. Når der ses på det forsikrede område på landsplan, er det kun ca. $18 \%$ af de aktiverede, der er visiteret til et ordinært uddannelsesforløb (Villumsen \& Vilhelmsen, 2017). En spørgeskemaundersøgelse gennemført i 2016 viste tilmed, at uddannelse - på trods af de nye muligheder i lovgivningen - sjældent er omdrejningspunktet i de samtaler, jobcentrene og a-kasserne holder med ledige (EVA, 2017). Meget tyder således på, at kommunerne holder fast i en beskæftigelsespolitik, der flugter mere med work first end human kapital-strategien.

Når der ses på aktiveringspraksis i de enkelte kommuner, bliver billedet dog langt mere nuanceret. Der er markante forskelle på kommunernes anvendelse af uddannelsesredskabet. F.eks. får mere end $50 \%$ af de aktiverede dagpengemodtagere i Hjørring Kommune uddannelse, imens det i kommu- ner som Herlev og Gladsaxe er under 3\%. Der er altså kommuner, der i høj grad er vendt tilbage til human kapital-sporet, imens mange fortsat prioriterer anderledes (Se bilag 1 for en samlet oversigt over kommunernes anvendelse af uddannelsesaktivering).

Men hvorfor er der så store forskelle på kommunernes tilgange til beskæftigelsesindsatsen? I artiklen udpeger vi en række faktorer, der kan tænkes at have relevans for kommunernes beskæftigelsespolitiske prioriteringer, og vi undersøger deres betydning i forhold den konkrete anvendelse af uddannelsesaktivering. Vi forsøger dermed at bidrage til litteraturen om dansk arbejdsmarkedspolitik, der er rig på analyser, der skitserer den overordnede policy-udvikling på feltet (Jørgensen, 2006; 2009; Jørgensen et al., 2017; Kvist \& Harsløf, 2014 Rosdahl \& Weise, 2000; Torfing, 2004), analyser af organisatoriske og institutionelle ændringer (Bredgaard \& Larsen, 2006; 2009; Breidahl \& Seemann, 2009; Damgaard, 2011) samt studier af beskæftigelsespolitikkens effekter (Munch \& Skipper, 2008'; Rosholm \& Svarrer, 2004). Litteraturen synes dog at mangle studier, der analyserer kommunernes aktiveringspraksis og variationer i denne. Larsen (2011) er en vigtig undtagelse, men han ser alene på kommunernes aktiveringspraksis i forhold til gruppen af kontanthjælpsmodtagere. Artiklen har dermed først og fremmet et empirisk sigte, men vi bruger teori til at udlede tre hypoteser, der guider vores undersøgelsesdesign.

Den første hypotese trækker på systemteori og funktionalisme (Fuglsang, 2014) og antager, at kommunernes beskæftigelsesindsatser er funktionelt tilrettelagt i forhold til det lokale arbejdsmarked. Variationer i kommunernes tilgange til aktivering af ledige kan i den optik skyldes, at der er forskel på kommunernes arbejdsmarkedsrelaterede udfordringer og behov. F.eks. kan vi antage, 
at kommuner med mange ufaglærte ledige bruger mere uddannelse end kommuner, hvor det er akademikere, der tager plads i arbejdsløshedskøen.

Den anden hypotese finder inspiration $\mathrm{i}$ den historiske institutionalisme (HI) (Mahoney \& Thelen, 2010) på den måde, at vi anskuer beskæftigelsespolitikken som omstridt policy-område, hvor Socialdemokratiets og venstrefløjens præferencer divergerer ret kraftigt fra de borgerlige parties. I den optik tolkes forskelle på kommunernes prioritering af uddannelse som udtryk for politiske forskelle, hvor kommuner med rødt flertal antages at være mere uddannelsesvenlige end blå kommuner.

Den tredje og sidste hypotese er inspireret af rational choice institutionalisme (RCI) (Peters, 1999) og går groft sagt ud på, at kommunerne beskæftigelsesindsats er præget af økonomisk kassetænkning. Mange - især økonomisk trængte - kommuner fravælger i den optik uddannelse, fordi det er en dyr aktiveringsform.

Vi gennemfører den empiriske undersøgelse med et datasæt konstrueret på baggrund af Jobindsats.dk, hvor det bl.a. er opgjort, hvor hyppigt forskellige aktiveringstilbud anvendes på kommuneniveau. I datasættet er desuden indlagt en række baggrundsvariabler, der hver især flugter med en af de tre hypoteser. Der benyttes tal fra 2016. Analysen indeholder dels en deskriptiv analyse, dels en multipel lineær regression med fire modeller.

Vi bygger artiklen op på følgende måde: I sektion 2 udvikler vi de tre hypoteser, der er skitseret ovenfor. I sektion 3 beskriver vi sammensætningen af vores datasæt og konstruktionen af vores variabler. I sektion 4 præsenteres analysen af datasættet. Femte og sidste sektion konkluderer og diskuterer analysens resultater.

\section{Kommunal aktivering mellem systemlogik, politik og økonomiske incitamenter?}

Hvorfor aktiverer kommunerne, som de gør? I dette afsnit formulerer vi tre hypoteser, om hvad der udgør de grundlæggende drivkræfter bag kommunernes beskæftigelsesindsats over for de forsikrede ledige. Teserne fungerer samtidig som nogle logiske bud på, hvorfor der forekommer så markante forskelle på kommunernes aktiveringspraksis og brugen af uddannelse.

Afsættet for at formulere de tre teser tages via en kort gennemgang af work first og human kapital-strategierne, der fra årtusindskiftet og op gennem 00'erne var den væsentligste sondring i forskningslitteraturen omkring policy-udviklingen indenfor det arbejdsmarkedspolitiske subsystem (Bredgaard \& Larsen, 2006; Bruttel \& Sol, 2006; Peck \& Theodore, 2001). Sidenhen er der i litteraturen beskrevet en række andre strategier (se Bredgaard et al., 2017 for en oversigt), hvoraf netvoerksstrategien også er relevant at fremhæve i et studie, hvor det er aktiveringen af forsikrede ledige, der er i fokus.

Work first-strategien har som udgangspunkt, at ledighed skyldes manglende motivation - f.eks. på grund af høje sociale ydelser. Derfor må de aktive indsatser handle om at motivere ledige til at søge arbejde hurtigere, oftere og mere bredt. F.eks. via obligatoriske jobsøgningskurser, korte virksomhedspraktikker eller nyttejob, hvis indhold sjældent opleves som nyttigt for den aktiverede. Målet er, at den ledige forlader arbejdsløshedskøen og kommer i arbejde - uanset hvilken type job, der er tale om, og uanset om jobbet matcher den lediges uddannelsesbaggrund og kvalifikationer (Bruttel \& Sol, 2006). Ud fra en betragtning, hvor beskæftigelsespolitikken ses som komplementær til 
den økonomiske politik, kan work first ses som instrument til at skabe et mere effektivt arbejdsudbud og dermed en vej til at forbedre lønkonkurrenceevnen, fordi de arbejdsløse nødes eller ligefrem tvinges til at acceptere prekære job med lave lønninger og ringe ansættelsessikkerhed - den såkaldte wage effect (Kvist \& Pedersen, 2007).

Human kapital-strategien ser derimod ledighed som et strukturelt problem, der affødes af globaliseringen og den teknologiske udvikling. Essensen er, at arbejdsløse mangler de kompetencer, som arbejdsgiverne efterspørger, og derfor må aktivering først og fremmest handle om omskoling eller opkvalificering. Målet er i og for sig det samme som for work first-strategien - nemlig at ledige kommer i ordinær beskæftigelse men vejen dertil går via andre redskaber og kræver flere investeringer (Bruttel \& Sol, 2006). Human kapital-strategien tilbyder således også en løsning på inflationsproblemer, fordi den forøger 'økonomiens kapacitet' og på den måde afhjælper flaskehalsproblemer, der under normale omstændigheder ville medføre opadgående lønpres (Peck \& Theodore, 2001).

Bredgaard et al. (2017) identificerer endnu en strategi, som de kalder netvoerkstrategien. Mange arbejdsgivere tilkendegiver, at de rekrutterer arbejdskraft via uformelle kanaler og netværk. Ledighed kan derfor skyldes, at de ledige mangler arbejdsmarkedsrelevante relationer, snarere end de mangler motivation eller faglige kompetencer. Det kan f.eks. være nyuddannede eller langtidsledige, der gradvist har mistet berøringen med arbejdsmarkedet. Netværksstrategien handler derfor om at styrke de lediges netværk og sociale kapital, f.eks. gennem løntilskudsjob eller længerevarende virksomhedspraktikker, hvor de i en periode får berøring med arbejdsmarkedet.

De forskellige strategier er idealtypiske konstruktioner. I virkelighedens verden vil forskellige problemer, indsatser og programmål eksistere sideløbende i den enkelte kommune. Men som vi har skitseret i indledningen, er der store forskelle på kommunernes redskabsanvendelse og dermed også på, hvor meget kommunerne prioriterer de forskellige strategier. Hypoteserne, vi formulerer i det følgende, udtrykker nogle forskellige rationelle bevæggrunde for at vægte henholdsvis work first, human kapital eller netvoerks-strategien i den enkelte kommune.

\section{Tese 1: Kommunernes beskceftigelsespolitik er funktionel i forhold til det lokale arbejdsmarked}

Vores første hypotese går ud på, at kommunerne aktiverer på den måde, der giver mest mening i det kommunale eller lokale arbejdsmarkedsperspektiv. Tesen afspejler en systemteoretisk tankegang, hvor genstandsfeltet betragtes som et mere eller mindre afgrænset system eller som en helhed, hvori de enkelte elementer optræder med en konkret funktionalitet. I systemteorien søges ikke efter årsags-virkningssammenhænge, da systemet og enkeltelementerne antages at interagere med hinanden. Systemet styres og bindes sammen af nogle principper, der tilskriver enkeltelementerne deres konkrete funktionalitet. Disse principper er dermed afgørende for aktøradfærd i systemet (Fuglsang, 2014).

I systemteoretisk optik kan vi anskue den kommunale beskæftigelsesindsats som element i en systemhelhed, der er kommunen eller det kommunale arbejdsmarked, imens systemets principper kan være de forskellige arbejdsmarkedspolitiske strategier. Den kommunale beskæftigelsesindsats må således tilrettelægges i forhold til det lokale arbejdsmarkeds beskaffenhed og udfordringer, og derfor vil indsatsen og de redskaber, der lægges vægt på, variere fra kommune til 
kommune og over tid. Hvis kommunen er 'systemet', er de beskæftigelsespolitiske intentioner, der udgår fra centraladministrationen, ikke så væsentlige.

Man kan argumentere for, at hypotesen afspejler en flexicurity-forståelse af det danske arbejdsmarked. I flexicurity-modellen anskues arbejdsmarkedet tillige som et system (Madsen, 2005), hvori beskæftigelsespolitikken har forskellige effekter. Man taler i den forbindelse om, at beskæftigelsespolitikken komplementerer dagpengesystemet og det fleksible arbejdsmarked, så moral hazard og underinvestering i efter- og videreuddannelse undgås eller afbødes (Bredgaard $\&$ Klindt, 2015).

Tesen er således åben for, at både human kapital, work first og netvaerks-tilgangen kan være i spil, men de tre strategier vægtes forskelligt alt efter hvilke problemer, den enkelte kommune har, og hvilke forudsætninger kommunen har for at hjælpe ledige tilbage på arbejdsmarkedet. F.eks. kan vi antage, at andelen af ufaglærte ledige og kommunernes brug af uddannelse er positivt korreleret, simpelthen fordi der er et funktionelt behov for mere opkvalificering, desto mere de ufaglærte fylder i den kommunale arbejdsløshedskø.

Ud fra en systemteoretisk betragtning kan ledighedsniveauet i kommunen også tænkes at ville påvirke brugen af uddannelse. Hvis ledigheden er lav som følge af gode konjunkturer, har kommunerne ofte gode forudsætninger for at få de resterende ledige i arbejde hurtigt, og dermed kan uddannelse umiddelbart virke som et overflødigt instrument. Omvendt vil højere ledighed og strukturledighed nødvendiggøre, at der er ledige, der gennemgår et kompetenceløft. Konjunkturerne og arbejdsstyrkens kvalifikationsniveau kan således tænkes at være vigtige faktorer. Det samme kan siges om erhvervsstrukturen i kommunen, der er afgørende for hvilke type arbejdskraft, der efterspørges.

\section{Tese 2: Politik betyder noget - også i kommuner og regioner}

Vores anden hypotese er inspireret af historisk institutionalisme (HI). I HI-optik er institutioner mekanismer, der fordeler magt og ressourcer. Institutioner vil derfor altid være politisk omstridte, og deres indretning vil afspejle den politiske magtbalance i samfundet, der var på det tidspunkt, institutionen blev etableret eller ændret (Thelen, 2010; Torfing, 2005). Et centralt begreb i HI er sporafhængighed. Sporafhængigheden handler om, at institutioner - når først de er etableret - sætter nogle rammer og vilkår for aktørernes fremtidige handlemuligheder (Larsen \& Andersen, 2005, s. 34-39).

Sporafhængighed er imidlertid ikke ensbetydende med stabilitet. Et institutionelt design vil ofte privilegere én samfundsgruppe og forfordele en anden. Dermed er grundlaget lagt for en ny politisk dynamik, hvor førstnævnte vil mobilisere kræfter for at bevare status quo, imens sidstnævnte vil kæmpe for institutionelle forandringer (Streek \& Thelen, 2005).

Institutionelle forandringer kan forekomme abrupt men også gradvist, f.eks. gennem en lang række af små justeringer, der på den lange bane alligevel fundamentalt ændrer institutionen. En pointe er her, at ændringer kan gennemføres som følge af det fortolkningsrum, der ofte findes i en institutionel arkitektur. Med andre ord: Hvis en institutionel reform er blevet til i et kompromis mellem politiske modstandere, vil der sandsynligvis være mulighed for, implementeringsaktørerne kan fortolke regelkomplekset i tråd med egne politiske præferencer; en forandringsform litteraturen benævner som conversion (Mahoney \& Thelen, 2010, s. 17-19).

Belyst med HI-briller må vi anskue hele det arbejdsmarkedspolitiske system og de beskæftigelsespolitiske strategier som et po- 
litisk omstridt felt. Men det ræsonnerer fint med det faktum, at der i Danmark er stærke politiske interesser indlejret i beskæftigelsessystemet. Socialdemokratiet og fagbevægelsen har således gennem årtier været fortaler for human kapital-strategien, hvor formålet har været at ruste arbejdsstyrken - først og fremmest fagbevægelsens medlemmer - til at kunne imødekomme omstillinger på arbejdsmarkedet.

Som det er dokumenteret flere steder i forskningslitteraturen, var 1990'ernes arbejdsmarkedspolitik under Nyrup Rasmussen netop drevet af ønsket om at tackle den høje ledighed via uddannelse, opkvalificering og øget mobilitet (Bredgaard et al., 2017; Jørgensen, 2002; Thelen, 2014; Torfing, 2004;). Det samme kan i nogen grad siges om 2015-reformen, der blev til under Thorning-Schmidts SR-regering. Reformen har som ovenfor nævnt åbnet nye muligheder for, at forsikrede ledige til og med KVU-niveau kan få et kompetenceløft i løbet af dagpengeperioden.

De borgerlige partier - først og fremmest Venstre og Konservative - har især abonneret på work first-strategien. Det sås f.eks. i 2000'ernes beskæftigelsespolitik, hvor VK-regeringen satte fokus på at få ledige hurtigst muligt tilbage på arbejdsmarkedet. Det første store reforminitiativ under VK-regeringen i 2000'erne var Flere $i$ arbejde fra 2003, der blandt andet tydeliggjorde aktiveringsviftens virksomhedsrettede tilbud og satte loft over brugen af uddannelse. Derudover strammede regeringen gentagne gange kravene til lediges jobsøgning og indskærpede a-kassernes forpligtelse til at føre rådighedskontrol med ledige (Bredgaard et al., 2017; Jørgensen 2006, s. 47-49).

Senere, i 2008, valgte VK-regeringen at afskaffe AF-systemet og erstatte det med de kommunale jobcentre, som vi kender i dag (Christiansen \& Klitgaard, 2009). Selvom denne reform først og fremmest var en administrativ reform, er den blevet tolket som yderligere et forsøg på at forstærke work first og svække human kapital-strategien. I det nye enstrengede kommunale beskæftigelsessystem blev arbejdsmarkedets parters indflydelse minimeret, og dermed var én af human kapital-strategiens vigtigste tilhængere - nemlig fagforeningerne - reelt sat ud af spillet om den lokale implementering af indsatsen (Bredgaard, 2011; Larsen, 2013).

Historien viser altså, at centrum-venstrepartierne og fagbevægelsen har været bannerfører for human kapital-strategien, imens de borgerlige har abonneret på work first-strategien og gradvis har forsøgt at skubbe systemet i den retning. Med hypotese nr. 2 overfører vi denne partipolitiske logik på kommunerne. Dermed antager vi, at socialdemokratisk styrede kommuner i højere grad end borgerlige anvender ordinær uddannelse i aktiveringsindsatsen. Vi kan lave denne kobling fra det nationale til det lokale niveau, fordi HI-perspektivet netop teoretiserer, at implementeringsaktørerne - her kommunerne - ofte vil have mulighed for at trække eller skubbe politikken i den retning, der passer dem bedst. Især når vi befinder os i et politisk omstridt subsystem, hvor de fleste reformer ikke desto mindre er forhandlet på plads af modstridende parter. Dette er præcis tilfældet på beskæftigelsesområdet, hvor det trods ideologiske forskelle har været kutyme at lave brede forlig henover midten af Folketinget (dog ikke kommunaliseringsreformen, der blev stemt hjem af et flertal udenom Socialdemokratiet).

Spørgsmålet er dog, om forskningen giver belæg for at overføre partipolitiske effekter fra det nationale til det lokale niveau? Det er sparsomt, hvad der eksisterer af forskning, der laver den kobling, men i en dansknorsk sammenhæng foreligger der faktisk et forskningsresultat, der synes at indikere en sammenhæng. Blom-Hansen, Monkerud \& Sørensen (2006) undersøgte gennem regres- 
sionsanalyser partipolitikkens betydning for skatteopkrævning og brugerbetaling på kommunalt niveau, og de fandt positive effekter af en venstreorienteret (socialdemokratisk) kommunalbestyrelse på skatteopkrævning og en negativ effekt på brugerbetaling i danske kommuner. I Norge fandt man samme positive effekt på skatteopkrævning men dog ingen effekt på brugerbetaling. Således er der altså et (om end småt) empirisk afsæt for at antage, at kommuner med en socialdemokratisk ledelse rent faktisk fører socialdemokratisk politik og borgerlige en mere liberal ditto.

Antagelsen om, at der indenfor omstridte policy-felters institutionelle strukturer ofte eksisterer et rum, der giver lokale aktører mulighed for at øve indflydelse, kan også bruges til at inddrage regionerne i vores analyse. Foruden sygehusvæsenet har regionerne $^{2}$ ansvar for regional udvikling og vækstpolitik, der bl.a. udmøntes med hjælp fra EU's strukturfonde. Via strukturfondsmidlerne og de udviklingsprojekter, der støttes, kan regionerne - i et vist omfang - sætte aftryk på kommunernes beskæftigelsespolitik. Eksempelvis har Region Midtjylland i en årrække forsøgt at fremme en kompetencebaseret vækstpolitik ved at bygge bro mellem uddannelses-, beskæftigelses- og erhvervsfremmesystemerne (se f.eks. http://www.kompetenceforsyningmidt.dk/). Regionen har dermed sat en dagsorden omkring uddannelse og opkvalificering, der er understøttet økonomisk og organisatorisk og som involverer alle regionens kommuner (Baadsgaard et al., 2016).

Det regionale niveau kan således - via vækstpolitikken - have betydning for den politik, der implementeres kommunalt, fordi regionerne har betydelige ressourcer at lægge bagved vækstpolitikken. Blandt de fem danske regioner er det især i Region Midtjylland og Region Nordjylland, der har ført en kompetencebaseret vækstpolitik, hvor forsyning af kvalificeret arbejdskraft til virksomhederne - herunder opkvalificering af ledige - spiller en afgørende rolle. På den baggrund kan vi antage, at der vil være regional variation $i$ brugen af uddannelse i aktiveringsindsatsen, og at det vil være i de midt- og nordjyske kommuner, vi skal finde den største brug af uddannelsesredskabet.

\section{Tese 3: Kommunernes beskaftigelses- indsats er styret af kassetcenkning}

Vores tredje hypotese er udledt af en anden gren af nyinstitutionel teori, nærmere bestemt rational choice institutionalisme (RCI). RCI kombinerer den nyinstitutionelle optiks blik for, at institutioner strukturerer eller påvirker aktørers adfærd, med antagelsen om at aktøradfærd grundlæggende handler om nyttemaksimering. Teorien betoner dermed økonomisk konsekvenslogik indenfor rammerne af institutionelle omgivelser. I RCI lægges f.eks. vægt på institutioner som love, regler og sanktioner, der kan bidrage til at forhindre snyd og sikre overholdelse af aftaler. Institutioner kan også bruges til at styre eller regulere adfærd mere indirekte, f.eks. via økonomiske incitamenter. En principal kan således bruge institutioner til at skabe incitament til, at agenter handler på en for principalen ønskværdig måde. På den måde kan institutioner skabe retning og styring $i$ en verden befolket af nyttemaksimerende aktører (Peters, 1999).

Overført til studiet af beskæftigelsesindsatsen i Danmark kan RCI bruges til at anskueliggøre, hvordan staten via refusioner har forsøgt at incitamentstyre kommunernes implementering af den aktive beskæftigelsespolitik - også kaldet metastyring af beskæftigelsespolitikken (Sørensen \& Torfing, 2011).

I forbindelse med kommunaliseringen af beskæftigelsesindsatsen i 2008 vedtog Folketinget en finansieringsmodel, der med statslig medfinansiering overvæltede dagpenge- 
og aktiveringsudgifterne til kommunerne. I modellen var indbygget, at kommunerne fik refusion fra staten for en del af dagpengeudgiften, herunder at refusionssatsen var højere, når ledige var i aktivering.

I en analyse i Samfundsøkonomen konkluderede Nørgaard (2009), at finansieringsmodellen - under indtryk af de dårlige konjunkturer - først og fremmest ville give kommunerne incitament til at aktivere ledige i "den billigste og nemmest tilgaengelige form for aktivering" (Ibid., s. 39-40). Uddannelse falder næppe under denne kategori. Uddannelse medfører deltagerbetaling - dvs. påfører kommunen en driftsudgift oveni dagpengeudgiften, det lægger op til længerevarende aktiveringsforløb og nødvendiggør koordination med både a-kasser og relevante uddannelsesinstitutioner.

Med afsæt i RCI og beskæftigelsessystemets finansieringsmodel kan vi således antage, at kommunernes aktiveringspraksis er styret af kortsigtet kassetænkning, hvilket medfører, at kommunerne først og fremmest forsøger at 'vende de ledige i døren', sekundært aktiverer dem i billige aktiveringsforanstaltninger med henblik på at spare penge og optimere refusion. Denne antagelse stemmer fint overens med udviklingen i kommunernes aktiveringspraksis efter 2009, hvor brugen af den dyre aktiveringsform - uddannelse - stagnerede på trods af stigende ledighed og aktivering generelt.

I forlængelse af beskæftigelsesreformen fra 2014 blev refusionsmodellen dog ændret, så der fra og med 1. januar 2016 gives refusion for $50 \%$ af driftsudgifterne, når ledige er i ordinær uddannelse, imens vejledning og afklaringsforløb ikke længere udløser refusion. Dernæst blev den del af modellen, der vedrører overførsler, ændret, således refusionssatsen for dagpenge (og andre overførsler) falder, jo længere tid den ledige går ledig - den såkaldte refusionstrappe. Et vigtigt spørgsmål er derfor, om refusionsreformen understøtter beskæftigelsesreformens ambi- tioner om uddannelsesløft? Er der kongruens eller mangel på samme mellem policy og økonomisk styringsmodel?

Dette spørgsmål blev diskuteret af beskæftigelsespolitikkens interessenter, imens forhandlingerne om refusionsreformen pågik $\mathrm{i}$ 2015. Der var enighed om, at reformen nok ville sætte en stopper for kommunernes 'aktiveringscirkus', men fra LO's side var man bekymret for, om "de loengerevarende uddannelsesindsatser, der kan få folk i permanent beskaeftigelse, går fløjten, fordi kommunerne vil toenke kortsigtet" (Dørge, 2015). Fra LO's side tvivlede man altså på, om omlægningen af driftsrefusionen ville få nogen betydning, når ydelsesrefusionerne - grundet refusionstrappen - samtidig har en ugunstig virkning i forhold til længerevarende forløb, f.eks. forløb hvor ufaglærte løftes til faglært niveau.

En nyere interviewundersøgelse gennemført af konsulentfirmaet M-ploy (2017) bekræfter bekymringen for, at refusionssystemet samlet set stadig ikke giver kommunerne incitament til at investere i uddannelse. M-ploys undersøgelse viser, at kommunerne generelt finder styringen og finansieringen af beskæftigelsesområdet meget kompleks, men dernæst at "refusionsomloegningen først og fremmest har sat fokus på, at det er centralt for kommunernes økonomi at nedbringe det samlede antal ydelsesmodtagere" (Ibid.,s. 12). Samtidig hedder det, at statens muligheder for at påvirke kommunernes konkrete valg af aktiveringsredskaber via driftsrefusion er begrænset (Ibid., s. 58).

Hvis kommunerne spekulerer i at optimere refusion og $i$ at holde driftsudgifterne nede på beskæftigelsesområdet, har vi en generel forklaring på den lave brug af uddannelsesaktivering i Danmark. Men til tesen vil høre den nuancering, at vi kan formode, at de økonomisk set mest trængte kommuner vil have den laveste brug af uddannelse. Omvendt er det sandsynligt, at uddannelsesinvesteringer er mere hyppige i kommuner med lidt mere luft i budgettet. 
Arbejdsmarkedspolitiske strategier

\begin{tabular}{|c|c|c|c|}
\hline & $\begin{array}{l}\text { Work first } \\
\text { (lav brug af udd.) }\end{array}$ & $\begin{array}{l}\text { Human kapital } \\
\text { (høj brug af udd.) }\end{array}$ & $\begin{array}{l}\text { Netværk } \\
\text { (lav brug af udd.) }\end{array}$ \\
\hline Tese 1: Systemlogik & $\begin{array}{l}\text { Kommuner med lav } \\
\text { ledighed }\end{array}$ & $\begin{array}{l}\text { Kommuner med } \\
\text { mange kortuddanne- } \\
\text { de ledige }\end{array}$ & $\begin{array}{l}\text { Kommuner med } \\
\text { mange ledige } \\
\text { dimittender }\end{array}$ \\
\hline Tese 2: Politisk logik & Blå kommuner & $\begin{array}{l}\text { Røde kommuner } \\
\text { og/ eller kommuner } \\
\text { i regioner, der fører } \\
\text { kompetencebaseret } \\
\text { vækstpolitik }\end{array}$ & \\
\hline $\begin{array}{c}\text { Tese 3: Økonomisk } \\
\text { logik }\end{array}$ & $\begin{array}{l}\text { Økonomisk trængte } \\
\text { kommuner }\end{array}$ & $\begin{array}{l}\text { Velbeslåede } \\
\text { kommuner }\end{array}$ & $\begin{array}{l}\text { Økonomisk trængte } \\
\text { kommuner }\end{array}$ \\
\hline
\end{tabular}

Sætter vi de tre hypoteser om drivkræfterne bag kommunernes beskæftigelsesindsatser overfor de tre idealtypiske arbejdsmarkedspolitiske strategier, bliver resultatet en række forskellige teoretiske udfaldsmuligheder. Teserne giver således ikke noget entydigt svar på, hvorfor nogle kommuner bruger meget uddannelse, imens andre bruger lidt eller næsten ingenting. De er i nogen grad konkurrerende. Men med teserne har vi et teoretisk bagtæppe for at udvælge forskellige baggrundsvariabler, der kan tænkes at være sammenhængende med omfanget af kommunens uddannelsesbrug.

\section{Metode og datasæet}

Med henblik på at efterprøve hypoteserne har vi konstrueret et datasæt med data fra Styrelsen for Arbejdsmarked og Rekrutterings (STAR) arbejdsmarkedsdatabase (www. jobindtsats.dk), Økonomi- og Indenrigsministeriets nøgletalsdatabase (www.noegletal.dk), KL og Danmarks Statistik. Alle de indhentede oplysninger er fra kalenderåret 2016. 2016 er valgt, fordi det er det seneste år, hvorfra der er tilgængelige tal, men også fordi 2016 er på behørig afstand af det forudgående kommunal- og regionsrådsvalg, der fandt sted i 2013. Et nyt byrådsflertal har således haft mulighed for at vedtage en ny politik, og politikken har haft mulighed for at 'virke' i en rum tid. I forhold til partipolitikkens betydning ville det have været uhensigtsmæssigt at vælge f.eks. 2014, fordi det som bekendt tager tid at implementere ny politik.

Den afhængige variabel i datasættet måler, hvor stor en procentandel af de aktiverede dagpengemodtagere i kommunen, der har fået ordinær uddannelse som led i deres aktivering. Variablen er således lig med antallet af uddannelsesaktiverede divideret med det samlede antal aktiverede.

I datasættet indgår 94 ud af de 98 danske kommuner. Læsø, Samsø, Fanø og Ærø kommuner er frasorteret datasættet, dels fordi både Læsø og Samsø var outliers, og dels fordi der i alle fire tilfælde er tale om små ø-kommuner, hvor selv små udsving i brugen af uddannelsesaktivering ville have 
haft stor betydning for den afhængige variabel.

En række uafhængige (forklarende) variabler inkluderes i analysen og er udvalgt med afsæt i de tre hypoteser. På baggrund af vores første tese, som er at kommunernes beskæftigelsesindsats er funktionel i forhold til det lokale arbejdsmarked, er der inkluderet tre variabler. For det første inddrages ledighedsniveauet i kommunen og dernæst en variabel, der måler andelen af de ledige, der er ufaglærte. Ud fra en funktionel betragtning er det plausibelt, at kommuner med høj ledighed eller mange ufaglærte ledige i højere grad vil satse på opkvalificering og kompetenceløft end kommuner med lav ledighed eller få ufaglærte ledige.

Endelig inddrages STARs inddeling af kommunerne i forskellige kommuneklynger. STAR inddeler kommunerne i syv klynger, alt efter hvor gode rammevilkår de har for deres beskæftigelsesindsats. Der er tale om en variabel, der både tager højde for ledigheden, alderssammensætningen og uddannelsesniveauet blandt de ledige, ligesom forhold vedrørende efterspørgselssiden på arbejdsmarkedet, boligforhold, mm. også er indregnet (Graversen et al., 2013). Klyngeinddelingen er forskellig fra ydelsesgruppe til ydelsesgruppe, så vi bruger naturligvis den inddeling, der vedrører de forsikrede ledige. Skalaen er indrettet sådan, at klynge 1 har de dårligste rammevilkår, imens klynge 7 har de bedste. Vores antagelse er i den forbindelse, at kommuner med mindre gode rammevilkår i højere grad vil satse på uddannelse i beskæftigelsesindsatsen. Ikke alene for at øge de lediges human kapital med også for at sikre, at kompetenceniveauet blandt de ledige kommer til at matche virksomhedernes efterspørgsel bedre.

På baggrund af vores tese nummer 2, politik-hypotesen, er der inkluderet to variabler. Den første variabel er en kategorisk variabel, der angiver om den siddende borg- mester i kommunen er rød eller blå. Radikale og socialdemokratiske borgmestre er kategoriseret som 'røde', mens konservative og Venstre-borgmestre er kategoriseret som 'blå'. Såfremt borgmesteren er fra en lokalliste, er lokallistens politiske standpunkter blevet undersøgt, og der er blevet foretaget en kategorisering efter en konkret vurdering. Hypotesen er som sagt, at kommuner med røde borgmestre i højere grad end blå vil bruge uddannelse i beskæftigelsesindsatsen. Den næste variabel - ligeledes kategorisk indikerer hvilken region, kommunen tilhører. Regionsvariablen er som skrevet ovenfor inkluderet, fordi regionerne via vækstpolitikken kan påvirke kommunernes beskæftigelsesindsats og støtte projekter, der sigter at styrke lediges kvalifikationer og løfte ufaglærte til faglært niveau.

Ud fra vores tredje tese, der baserer sig på RCI, er der inkluderet en enkelt forklarende variabel. Variablen, der inddrages, er et socioøkonomisk indeks fra Økonomi- og Indenrigsministeriets nøgletalsdatabase. Det socioøkonomiske indeks måler kommunens relative udgiftsbehov sammenlignet med andre kommuner. Det socioøkonomiske indeks har siden 1996 været anvendt til kommunal udligning. Indekset siger således noget om, hvordan den enkelte kommune er stillet rent økonomisk. Værdier, der er mindre end ' 1 ' i indekset, betyder, at kommunen har et lavere udgiftsbehov end det kommunale landsgennemsnit, højere værdier vice versa. De mest velstillede kommuner finder vi altså i den lave ende af indekset, imens de dårligst stillede kommuner ligger i den høje ende. Variablen er inkluderet, fordi vi med afsæt i tese 3 antager, at mange kommuner - især dem, der er økonomisk hårdt trængt - har incitament til at lave beskæftigelsespolitisk kassetænkning og derfor går uden om uddannelsesredskabet, der er dyrt og belaster kommunens økonomi. Variablen anvendes i sin oprindelige form i regressionsanalysen, 
dvs. som en intervalskaleret variabel (gennemsnit $=0,97$, minimum 0,52 , maksimum $1,63)$.

Tre yderligere kontrolvariabler inkluderes i analysen. Der drejer sig om kommunens indbyggertal, andelen af aktiveringsberørte dagpengemodtagere i forhold til det totale ledighedstal og endelig aktiveringsgraden, der fortæller os, om de aktiverede er aktive på fuld tid eller mindre. Til analysen af talmaterialet anvendes lineær regression (Ordinary Least Squares).

\section{Analyse}

I det følgende gennemgår vi den statistiske analyse af vores datasæt. Vi indleder med at præsentere tre deskriptive analyser, hvorefter vi kaster os over regressionsanalysen, der undersøger brugen af uddannelse (den afhængige variabel) som funktion af de udvalgte baggrundsvariable.
Søjlediagrammet i figur 1 viser, hvorledes de 94 kommuner fordeler sig i forhold deres anvendelse af ordinær uddannelse i beskæftigelsesindsatsen. Diagrammet er inddelt $i$ fremprocentsintervaller. Den første søjle viser således, hvor mange kommuner der bruger mellem 0 og $5 \%$ uddannelse (3 kommuner). Næste søjle viser, hvor mange der bruger mellem 5 og 10\% (14 kommuner) osv.

Af søjlediagrammet fremgår det videre, at den typiske brug af uddannelse ligger på mellem 15 og 20\%. Det er tilfældet for 24 kommuner. Det samlede gennemsnit for brugen af uddannelse ligger på 18,5\%, mens medianen ligger lidt under gennemsnittet på $16,6 \%$. Hele 37 kommuner bruger mindre end $15 \%$ uddannelse. 30 kommuner bruger mellem 20 og $40 \%$. I søjlediagrammet ses også en outlier, der ligger meget højt. Det drejer sig om Hjørring Kommune, hvor 51,8\% af de aktiverede modtog ordinær uddannelse i 2016.

Figur 1: Kommunernes brug af uddannelse i beskoeftigelsesindsatsen (2016)

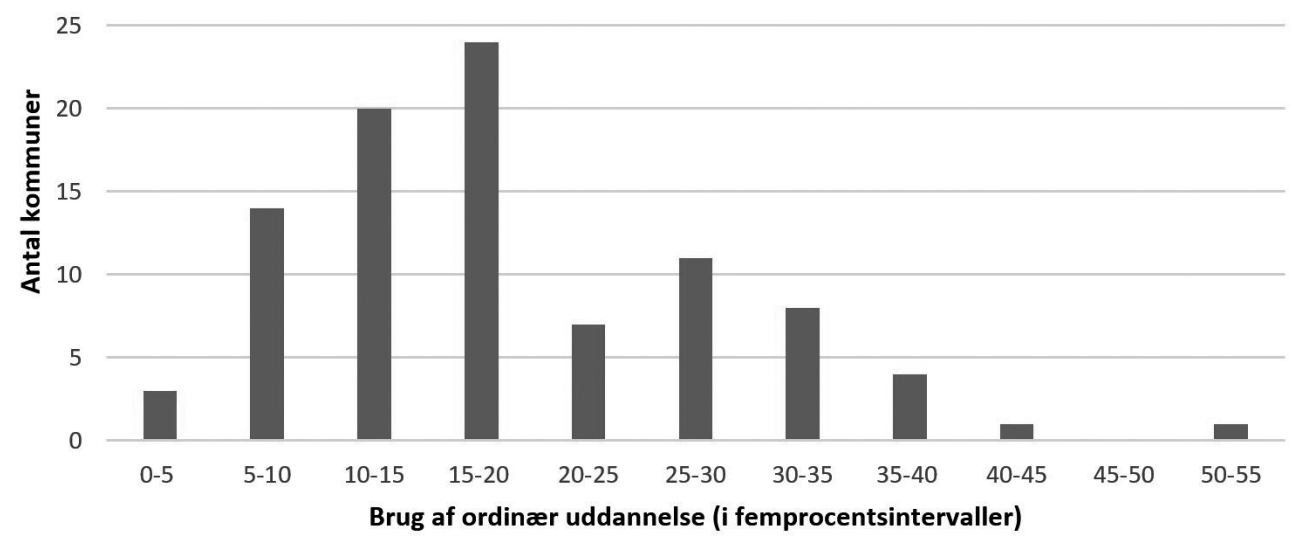

Kilde: Jobindsats.dk

Som det ses i figur 1, er der meget stor variation i kommunernes brug af uddannelse i aktiveringsindsatsen. Men er der et mønster i forhold til hvilke kommuner, der bruger henholdsvis meget eller lidt uddannelse? Af tabel 2 ser vi, at Gladsaxe er den kommune, der bruger mindst 
uddannelse - tæt efterfulgt af Herlev Kommune. Fokuserer vi på de ti kommuner, der ligger lavest i datasættet, er der én tydelig fællesnævner. De er alle sjællandske kommuner, og de fleste af dem ligger i hovedstadsområdet.

Som allerede beskrevet er Hjørring den kommune, der bruger mest uddannelse i aktiveringsindsatsen. Ser vi på kommunerne i topti, er det værd at bemærke, at syv af dem ligger i et bælte langs den jyske vestkyst fra Ringkøbing-Skjern Kommune i syd over Holstebro, Lemvig, Thisted, Jammerbugt og
Hjørring til Frederikshavn Kommune i nord. Disse kommuner udgør den nordlige del af den såkaldte 'rådne banan' - et udtryk, der gennem en årrække er blevet anvendt til at karakterisere yderområder i Danmark præget at økonomisk og befolkningsmæssig tilbagegang (Winther \& Svendsen, 2012). Hos dem alle udgør brugen af uddannelse mere end $33 \%$ af aktiveringsindsatsen. Når vi analyserer 'topscorerne' og 'bundskraberne' i vores datasæt, er det altså først og fremmest geografiske mønstre, der træder frem.

Tabel 2: De ti kommuner med henholdsvis den laveste og den højeste brug af uddannelse

\begin{tabular}{llll} 
Bund 10 & Procent & Top 10 & Procent \\
Gladsaxe & 2.9 & Hjørring & 51.8 \\
\hline Herlev & 3.0 & Frederikshavn & 40.3 \\
\hline Frederiksberg & 4.2 & Lemvig & 39.3 \\
\hline Glostrup & 4.2 & Fredericia & 37.9 \\
\hline Lyngby-Taarbæk & 5.2 & Thisted & 36.2 \\
\hline Solrød & 5.5 & Ringkøbing-Skjern & 35.6 \\
\hline Hørsholm & 6.1 & Jammerbugt & 34.7 \\
\hline Vordingborg & 6.6 & Faaborg-Midtfyn & 34.5 \\
\hline Næstved & 6.9 & Horsens & 33.2 \\
\hline Rudersdal & 7.0 & Holstebro & 33.1 \\
\hline
\end{tabular}

Kilde: Eget datasaet konstrueret på baggrund af data fra blandt andet jobindsats.dk

Inden vi kommer til regressionsanalysen, skal vi se på, om der forekommer binære sammenhænge mellem den afhængige variabel og et udsnit af de uafhængige variabler, vi har identificeret på baggrund af vores hypoteser. Det gør vi i tabel 3. I tabellen ses det, at andelen af ledige, der har fået ordinær uddannelse, er næsten 5 procentpoint højere i kommuner 
med en rød borgmester sammenlignet med kommuner med en blå ditto. Ser vi på brugen af uddannelse fordelt på regioner, er Region Nordjylland i top efterfulgt af de øvrige jyske regioner. Når Storebælt krydses, falder brugen af ordinær uddannelse i aktiveringsindsatsen betydeligt - i Region Sjælland og i Region Hovedstaden er den gennemsnitlige brug af uddannelse på henholdsvis 14,4\% og 13,2\%.
Dernæst ser vi på, om der skulle være sammenhæng mellem dagpengeklynge og brugen af uddannelse. Som det erindres, beskriver klyngerne ud fra både udbuds- og efterspørgselsfaktorer, hvor gode rammevilkår kommunerne har for at få dagpengemodtagere i beskæftigelse. Jo lavere værdien er, jo mere vanskelige er kommunens rammevilkår.

Tabel 3: Gennemsnitlig brug af ordinoer uddannelse $i$ kommunerne fordelt på udvalgte baggrundsvariabler

\section{Borgmesterfarve}

\section{Borgmesterfarve}

Blå Kommune

17,1

Rød Kommune

\section{Region}

Nordjylland 26,8

Midtjylland

Syddanmark

Sjælland

14,4

Hovedstaden

13,2

\section{Kommuneklynge}

Klynge 1

Klynge 2

Klynge 3

Klynge 4 17,8

Klynge 5 16,3

Klynge 6 12,2

Klynge 7 7,5 
Sammenhængen i tabellen er tilnærmelsesvis lineær, hvad angår kommuneklyngen, således at kommuner med vanskelige rammevilkår anvender mest uddannelse, mens kommuner med gunstige vilkår anvender mindst (kommunerne i klynge 2 anvender mest). Af samme årsag inddrages variablen som en intervalskaleret variabel i regressionsanalyserne i tabel 4 . Det er muligt, at de binære sammenhænge i tabel 3 forsvinder, når der kontrolleres for øvrige faktorer. Formålet med regressionsanalysen er netop at undersøge om sammenhænge forsvinder, når der tages højde for andre faktorer, hvilket vi bevæger os videre til i det følgende.

I tabel 4 ses resultatet af regressionsanalysen. Tabellen er inddelt i fire forskellige modeller, der kronologisk følger vores hypotesegennemgang og dermed trin for trin inddrager stadig flere baggrundvariabler. I model 1 inddrages således kun de variabler, der afspejler den funktionelle hypotese, dvs. ledighedsniveau, andelen af ufaglærte ledige og endelig kommuneklyngevariablen. I model 2 tilføjes de variabler, der afspejler politik-hypotesen, dvs. borgmesterfarveog regionsvariablen. I model 3 tilføjes det socioøkonomiske indeks, der afspejler den tredje tese om økonomisk kassetænkning, og til slut i model 4 inkluderes de øvrige kontrolvariabler i form af indbyggertal, aktiveringsgrad og andel aktiveringsberørte.

Ser vi på resultaterne i model 1, er det udelukkende kommuneklyngevariablen, der er statistisk signifikant. Ved en stigning i kommuneklyngekategori (f.eks. fra klynge 3 til klynge 4) falder brugen af uddannelse med 3 procentpoint. Dvs., jo bedre rammevilkår for beskæftigelsesindsatsen, jo mindre brug af uddannelse.

I model 2 tilføjer vi de variabler, der afspejler de politiske faktorer. Her bliver borgmesterfarvevariablen og dele af regionsvariablen statistisk signifikante. Når der kontrolleres for de øvrige variabler i model- len, bruger kommuner med en rød borgmester 4 procentpoint mere uddannelse end kommuner med en blå borgmester. I forhold til regionsvariablen er Region Nordjylland brugt som referencekategori. Vi ser ud fra resultaterne, at kommuner, der er placeret i Region Syddanmark, Region Sjælland eller Region Hovedstaden, bruger mindre uddannelse sammenlignet med kommuner i Region Nordjylland. Forskellen er på 6 procentpoint for Region Syddanmark, 15 procentpoint for Region Sjælland og 14 procentpoint for Region Hovedstaden. I modellen finder vi således opbakning til antagelserne om, at kommunal- og regionalpolitik har betydning for implementeringen af beskæftigelsesindsatsen.

Værd at bemærke er også, at kommuneklyngevariablen i model 2 ikke længere er signifikant, men at variablen, der måler andelen af ufaglærte ledige i kommunen, nu er det. Når andelen af ufaglærte stiger med ét procentpoint, stiger brugen af uddannelse med 0,5 procentpoint. Model 2 giver således også opbakning til den funktionelle hypotese, i hvert fald hvad angår sammenhængen mellem de lediges uddannelsesniveau og brugen af uddannelse.

Bevæger vi os videre til model 3, ser vi grundlæggende de samme resultater med hensyn til både de funktionelle og de politiske forklaringer som i model 2. Tilføjelsen af det socioøkonomiske indeks, der operationaliserer hypotesen om kommunal kassetænkning, ændrer ikke på sammenhængene, og variablen er ikke signifikant.

I model 4 tilføjes de resterende variabler i form af indbyggertal, aktiveringsgrad og andelen af aktiveringsberørte blandt kommunens dagpengemodtagere. Variablen, der måler andelen af ufaglærte ledige, er fortsat signifikant i model 4 . Bevæger vi os videre til de politiske variabler, ser vi, at kommuner med en rød borgmester nu anvender cirka 5 procentpoint mere uddannelse end 
blå kommuner, når der kontrolleres for de $\varnothing$ vrige variabler i model 4 . Ligeledes bruger kommuner i Region Sjælland og Region Hovedstaden fortsat mindre uddannelse end kommuner i Region Nordjylland (henholdsvis 14 og 12 procentpoint mindre), men der er ikke længere en signifikant effekt, når Syddanmark sammenlignes med Nordjylland.

Det socioøkonomiske indeks, der afspejler vores kassetænkningshypotese, er fortsat ikke statistisk signifikant i model 4.

Kun en enkelt af vores kontrolvariabler er signifikant i modellen. Der er tale om variablen, der måler andelen af aktiveringsberørte dagpengemodtagere (altså hvor stor en del af kommunens dagpengemodtagere, der er i aktivering). Sammenhængen er signifikant med en negativ koefficient. Brugen af uddannelse falder med knap 0,4 procentpoint, når andelen af aktiveringsberørte stiger med ét procentpoint. Jo flere der aktiveres, jo mindre udgør altså andelen af uddannelsesaktivering. En plausibel forklaring herpå kan være, at uddannelsesaktivering er dyrt sammenlignet med f.eks. virksomhedspraktik, der er et udgiftsneutralt instrument for kommunen. Hvis en kommune har en ambition, der først og fremmest handler om, at så mange som muligt skal aktiveres, vil uddannelse derfor relativt set komme til at fylde mindre, da kommunen - alt andet lige - må tænkes at ville prioritere udgiftsneutrale aktiveringsforløb. 
Tabel 4: Hvilke faktorer påvirker kommunernes brug af uddannelse i beskaeftigelsesindsatsen? Lineaer regression (OLS regression) med kommunernes brug af ordinoer uddannelse som afhoengig variabel.

\begin{tabular}{|c|c|c|c|c|}
\hline & Model 1 & Model 2 & Model 3 & Model 4 \\
\hline & Koefficient & Koefficient & Koefficient & Koefficient \\
\hline Ledighed & -1.36 & -.13 & .76 & .89 \\
\hline $\begin{array}{l}\text { Andel ufaglærte } \\
\text { ledige }\end{array}$ & .24 & $.52^{\star * *}$ & $.58^{* * *}$ & $.49^{* *}$ \\
\hline Kommuneklynge & $-3.04^{\star * *}$ & -1.16 & -1.36 & -1.24 \\
\hline \multicolumn{5}{|l|}{ Borgmesterfarve } \\
\hline Blå & Ref. & Ref. & Ref. & Ref. \\
\hline Rød & & $4.16^{* *}$ & $4.39^{* *}$ & $4.88^{\star * \star}$ \\
\hline \multicolumn{5}{|l|}{ Region } \\
\hline Nordjylland & Ref. & Ref. & Ref. & Ref. \\
\hline Midtjylland & & -4.51 & -3.80 & -3.06 \\
\hline Syddanmark & & $-6.24^{\star *}$ & $-5.61^{*}$ & -4.91 \\
\hline Sjælland & & $-14.78^{* * *}$ & $-14.34^{* * *}$ & $-13.91^{\star * *}$ \\
\hline Hovedstaden & & $-14.22 * * *$ & $-13.39 * * *$ & $-11.71^{* * *}$ \\
\hline $\begin{array}{l}\text { Socioøkonomisk } \\
\text { indeks }\end{array}$ & & & -5.66 & -3.56 \\
\hline $\begin{array}{l}\text { Indbyggertal } \\
\text { (i tusinde } \\
\text { personer) }\end{array}$ & & & & -.006 \\
\hline Aktiveringsgrad & & & & .39 \\
\hline $\begin{array}{l}\text { Andel } \\
\text { aktiveringsberørte }\end{array}$ & & & & $-.36^{* *}$ \\
\hline Konstant & 26.21 & 13.87 & 14.41 & 21.69 \\
\hline $\mathrm{N}$ & 94 & 94 & 94 & 94 \\
\hline R2 & 0.22 & 0.47 & 0.47 & 0.50 \\
\hline
\end{tabular}

Kilde: Eget datasaet konstrueret på baggrund af data fra blandt andet jobindsats.dk *=signifikant på 0.10 niveau, ** signifikant på 0.05 niveau. ${ }^{* * *}=$ signifikant på 0.01 niveau. 
Sammenfattende finder vi således opbakning til især politik-hypotesen, idet analysen viser, at brugen af uddannelse hænger sammen med både borgmesterfarve og region. Endvidere giver analysen delvis opbakning til den funktionelle tese. Jo større andel ufaglærte ledige, der er i en kommune, jo mere bruges uddannelsesaktivering. Samlet set forklarer modellen $50 \%$ af variationen i de danske kommuners brug af uddannelse i beskæftigelsesindsatsen (R2 $=0.50$ ). Modellens forklaringskraft er således temmelig høj, og modellen må i den forstand siges at være ganske anvendelig til at prædiktere kommunernes brug af uddannelse.

\section{Konklusion og diskussion}

I denne artikel har vi undersøgt kommunernes brug af uddannelse i beskæftigelsesindsatsen for de forsikrede ledige i Danmark. Human kapital-strategien, der sigter på at løfte arbejdsløses kvalifikationer gennem uddannelse, udgjorde hovedsporet i dansk arbejdsmarkedspolitik tilbage i 1990'erne, men den blev gradvist rullet tilbage i 2000'erne som følge af politiske og administrative reformer. Særligt efter nedlæggelsen af AF-systemet og oprettelsen af de kommunale jobcentre faldt andelen af ledige, der blev visiteret til ordinære uddannelsesforløb som led i deres aktivering. Virksomhedsrettet aktivering og samtaler er siden blev de mest hyppige aktiveringsmåder.

På tværs af det kommunale landkort er der imidlertid store forskelle på, hvor meget kommunerne anvender uddannelsesredskabet. En håndfuld kommuner giver uddannelse til mere end hver tredje dagpengemodtager, imens en række kommuner stort set ikke bruger redskabet. De øvrige kommuner ligger et sted derimellem. På landsplan udgør uddannelse ca. 18\% af indsatsen (dvs. $18 \%$ af de aktiverede dagpengemodtagere får ordinær uddannelse som led i deres aktivering).

Med artiklen har vi ønsket at undersøge mulige årsager til de store kommunale forskelle. Dermed er artiklen et bidrag til den efterhånden store mængde af analyser af dansk beskæftigelsespolitik (Bredgaard et al., 2017; Jørgensen 2006; Kvist \& Harsløf 2014; Kvist \& Pedersen 2011; Larsen 2011; Torfing, 2004;), der dog sjældent analyserer forskelle i beskæftigelsespolitikken på kommunalt niveau.

Med henblik på at kunne forklare de forskelle, som kan observeres på tværs af kommunerne, har vi i artiklen formuleret tre hypoteser om bevæggrundene bag kommunernes beskæftigelsespolitiske prioriteringer. Teserne udpeger henholdsvis funktionelle, politiske og økonomiske forhold som logiske forklaringsfaktorer bag kommunernes prioritering af forskellige redskaber.

I vores datasæt inddrog vi en række tilgængelige variabler, der hver især korresponderer med én af de tre teser. I analysen undersøgte vi via lineær regression variablernes forklaringskraft i forhold til de observerede forskelle. Vi fandt blandt andet ud af, at der er statistisk sammenhæng mellem brugen af uddannelse og de arbejdsløses uddannelsesniveau. Hvis andelen af ufaglærte ledige i kommuner stiger med 1 procentpoint, stiger brugen af uddannelse med 0,5 procentpoint. Regressionsanalysen viste dog også, at ledighedsniveauet i sig selv ikke påvirker brugen af uddannelse. Sammenhængen mellem kommuneklynge og brugen af uddannelse var heller ikke signifikant. Resultatet giver således kun delvis opbakning til den funktionelle hypotese. Resultatet tyder på, at udbudssiden på det lokale arbejdsmarked har nogen betydning for aktiveringsindsatsen, men vi kan ikke dokumentere, at efterspørgselssiden har nogen betydning.

Analysen viste dernæst, at politik tilsyneladende er vigtig. Kommuner med røde 
borgmestre bruger mere uddannelse i beskæftigelsesindsatsen end kommuner med blå borgmestre. Når vi kontrollerer for de øvrige faktorer i datasættet, stiger brugen af uddannelse i gennemsnit med ca. fem procentpoint, hvis kommunen har en rød borgmester sammenlignet med en blå. Vores analyse viste også, at det har en selvstændig betydning, hvilken region kommunen er placeret i. Sammenlignet med kommuner i Region Nordjylland bruger kommuner i Region Sjælland og Region Hovedstaden en lavere grad af uddannelsesaktivering. Forskellen i brugen af uddannelse er på henholdsvis 14 og 12 procentpoint. Datamaterialet viste derforuden, at brugen af uddannelse er mest udpræget i kommunerne i Region Nordjylland og Region Midtjylland.

Analysen gav således opbakning hypotesen udledt af historisk institutionalisme, der betoner institutioners fordelingspolitiske betydning og det forhold, at institutioner ofte vil være politisk omstridte og uklare. Litteraturen om historisk institutionalisme har helt eksplicit blik for, at der inden for en institutionel struktur kan være rum for, at lokale aktører kan tone implementeringen af regler på en måde, som flugter med egne interesser eller overbevisninger. Denne antagelse er kongruent med beskæftigelseslovgivningen i Danmark, og den måde det beskæftigelsespolitiske system er organiseret og styret på. Lovgivningen indeholder muligheder for, at forskellige aktiveringsstrategier kan tages i anvendelse, men det er kommunernes jobcentre, der har ansvaret for implementeringen. Derfor er der i det kommunale system rum for, at man politisk kan prioritere nogle strategier højere end andre. Analysen i denne artikel peger i den forbindelse på, at der er en vis sammenhæng mellem partifarve og aktiveringsstrategi, og at det - som forventet - er de røde socialdemokratiske kommuner, der bruger mest ud- dannelse og dermed hælder mest til human kapital-strategien.

Hvad så med kassetænkningshypotesen? Analysen gav ikke medhold til, at der skulle være en sammenhæng mellem kommunens indplacering i det socio-økonomiske indeks og brugen af uddannelse. Så vi kan ikke umiddelbart sige, at økonomi har nogen effekt i forhold til hvordan kommunerne aktiverer. Men det kan vi måske alligevel. Analysen viste til slut, at andelen af aktiveringsberørte har negativ indflydelse på brugen af uddannelse. Dvs., den relative brug af uddannelse falder, jo flere ledige der er aktive. Egentlig inkluderede vi denne variable som en kontrolvariabel, men med henvisning til Nørgaard (2009) kan vi argumentere for, at den siger noget om økonomisk optimering. Som følge af refusionssystemets indretning har kommunerne længe haft incitament til - på den korte bane - at aktivere så meget som muligt og så billigt som muligt. Med andre ord; kommunerne har haft incitament til at lave mange virksomhedsrettede forløb, der som bekendt er udgiftsneutrale for kommunen, og lidt eller slet ingen uddannelse. Og det flugter med det generelle billede i vores analyse, som jo er, at uddannelse på landsplan ikke fylder meget i den samlede aktiveringsindsats.

Refusionssystemet er, som vi har skrevet $i$ artiklen, omlagt flere gange i løbet af 2010'erne, og faktisk er det blevet vanskeligere for kommunerne at styre med henblik på at optimere refusion. Men givetvis er der kommuner rundt om i landet, som holder fast i strategien om at aktivere mest muligt. Det betyder, at aktiveringsbudgettet skal fordeles ud på flere, og alt andet lige giver dette plads til færre uddannelsesforløb.

Vores analyse af kommunernes brug af uddannelse (se tabel 2) viser, at med undtagelse af Horsens, Fredericia og Fåborg-Midtfyn ligger samtlige af de kommuner, der bruger 
mest uddannelse, i den nordlige del af den såkaldte 'rådne banan'.

Men hvorfor er det i den 'rådne banan', vi først og fremmest kan observere en beskæftigelsespolitik med fokus på uddannelse og human kapital? Et svar kan være, at disse kommuner i særlig grad er udfordrede i forhold til at omstille arbejdsstyrken til nye muligheder på arbejdsmarkedet. I Vest- og Nordjylland har der i de senere år været vækst inden for det maritime område samt inden for vind- og energisektoren (Junker, 2015). Omstillingen af arbejdstyrken fra traditionel 'sort' fremstillingsindustri til de mere 'grønne' og 'blå' industrier kræver måske i særlig grad, at der sker omskoling og kompetenceudvikling? En anden grund kan være den fraflytning og befolkningsmæssige tilbagegang, der sker i udkantsområderne. Flere af kommunerne oplever mangel på arbejdskraft, hvilket kan have ansporet dem til at satse mere intensivt på at opkvalificere de ledige, de trods alt har. Denne sammenkædning er f.eks. udtrykt i Hjørring Kommunes beskæftigelsesstrategi (Hjørring Kommune, 2016).

En tredje observation, der er væsentlig at nævne, er, at mange af human kapital-kommunerne er pionerer i forhold til at etablere nye tværgående partnerskaber mellem erhvervs-, beskæftigelses- og uddannelsesområderne. Som beskrevet i forbindelse med politik-hypotesen har Region Midtjylland gennem en årrække via EU-støttede udviklingsprojekter forsøgt at fremme en kompetencebaseret vækstpolitik og større koordinering mellem de forskellige politikområder i regionens kommuner. Lignende tiltag er gjort i flere af de nordjyske kommuner, f.eks. i Hjørring, Jammerbugt og Frederikshavn. I det midtjyske har den nye partnerskabstankegang blandt andet slået rod i Horsens, Ringkøbing-Skjern og i Lemvig-Holstebro-Struerområdet (se Baadsgaard et al., 2016). Når de vest- og nordjyske kommuner er særlig uddannelsesvenlige, kan det altså også have at gøre med regionalpolitiske satsninger.

Datamaterialet og analysen, vi har fremlagt, peger altså på, at både kommunale og regionale politiske faktorer er afgørende for hvilke redskaber, der anvendes i beskæftigelsesindsatsen. Men de politiske faktorer bør ses i sammenhæng med de udfordringer og muligheder, den enkelte kommune har for at bringe ledige tilbage på arbejdsmarkedet og for sikre virksomhederne kvalificeret arbejdskraft. Sammensætningen af udbudssiden af arbejdsmarkedet synes også at have betydning.

Afslutningsvist er det vigtigt at huske på, at denne artikels analyse kun giver et øjebliksbillede af variationerne i den kommunale aktiveringspraksis. Med henblik på at styrke resultatet og de observerede statistiske sammenhænge er mere forskning i emnet påkrævet. Man kunne med fordel analysere udviklingen over tid, og teste om de politiske faktorer er konstante, eller om de også påvirkes, f.eks. af økonomiske konjunkturer?

En række danske kommuner er kendetegnet ved, at skiftende politiske flertal har haft magten, imens andre kommuner har haft stabile flertal gennem mere end 100 år. Skal man tættere på at måle partifarveeffekten på de lokale beskæftigelsesindsatser, burde man måske udelade de politiske mudrede kommuner, hvor ratsløreffekter givetvis skygger for billedet af de reelle politiske intentioner. Kvalitative casestudier ville på samme måde gøre os bedre i stand til at forstå hvilke drivkræfter, der er på spil i de enkelte kommuner. Det kunne f.eks. være nyttigt at komme tættere på de vest- og nordjyske kommuner, der bruger rigtig meget uddannelse, og de kommuner rundt omkring hovedstaden, hvor uddannelsesredskabet mest af alt synes at ligge på hylden og samle støv. 


\section{LITTERATURLISTE}

Baadsgaard, K., Jørgensen, H., Larsen, F. \& Lassen, M. S. (2016). Partnerskaber i støbeskeen: Uddannelses, beskoeftigelses- og erhvervspolitisk samarbejde om kompetenceudviklingsindsatser over for virksomhederne. Aalborg: CARMA (Center for Arbejdsmarkedsforskning ved Aalborg Universitet).

Blom-Hansen, J., Monkerud, L. C. \& Sørensen, R. (2006). Do parties matter for local revenue policies? A comparison of Denmark and Norway. European Journal of Political Research, 45(3), 445-465. https://doi.org/10.1111/ j.1475-6765.2006.00305.x

Bredgaard, T. (2011). When the Government Governs: Closing Compliance Gaps in Danish Employment Policies. International Journal of Public Administration, 34(12), 764 774. https:// doi.org/10.1080/01900692.2011.603231

Bredgaard, T. \& Larsen, F. (2006). Udliciteringen af beskaeftigelsespolitikken: Australien, Holland og Danmark. København: Jurist- og Økonomforbundets Forlag.

Bredgaard, T. \& Larsen, F. (2009). Regionale og lokale beskoeftigelsesråd - i spoendingsfeltet mellem stat og kommune. Aalborg: Aalborg Universitetsforlag.

Bredgaard, T. \& Klindt, M. P. (2015). Flexicurity og institutionel teori. I Bredgaard T. \& Madsen P. K. (red.), Dansk Flexicurity - fleksibilitet og sikkerhed på arbejdsmarkedet (). København: Hans Reitzels Forlag.Bredgaard, T., Jørgensen, H., Madsen, P.K. \& Rasmussen, S. (2017). Dansk arbejdsmarkedspolitik (2. udgave). København: Jurist- og Økonomforbundets Forlag.

Breidahl, K. \& Seemann, J. (2009). Jobcentret som organisatorisk foenomen. København: Frydenlund Academic.

Bruttel, O. \& Sol, E. (2006). Work First as a European model? Evidence from Germany and the Netherlands. Policy \& Politics, 34(1), s. 69-89. https://doi.org/10.1332/030557306775212142

Christiansen, P. M. \& Klitgaard, M. B. (2009). Som en tyv om natten. Etableringen af den enstrengede arbejdsmarkedsforvaltning. Samfundsøkonomen, 5, 5-9.
Damgaard, B. (2011). Metastyret netværksstyring i beskæftigelsespolitikken. I Damgaard, B. \& Sørensen, E. (red.), Styr på beskaeftigelsespolitikken (s. 55-80). Købehavn: Jurist- og Økonomforbundets Forlag.

Dørge, H. (2015). Ukendt, men hamrende vigtigt. Weekendavisen, 18. december.

EVA (2017). Lediges perspektiver på uddannelse ufagloerte dagpengemodtageres vurderinger af samtaler og uddannelse. Rapport udgivet af Danmarks Evalueringsinstitut.

Fuglsang, L. (2014). Systemteori og funktionalisme som forklaringsform. I Fuglsang, F., Olsen, P.B. \& Rasborg, K. (red.), Videnskabsteori i samfundsvidenskaberne (3. udgave, s. 231-256). Købehavn: Samfundslitteratur.

Graversen, B. K., Larsen, M. \& Arendt, J. N. (2013). Kommunernes rammevilkår for beskaftigelsesindsatsen. København: SFI.

https://www.sfi.dk/publikationer/kommunernes-rammevilkaar-for-beskaeftigelsesindsatsen-3666/

Hjørring Kommune (2016). Investering $i$ arbejdsrettet rehabilitering. Arbejdsmarkedsforvaltningen i Hjørring Kommune.

Junker, F. (2015). Massiv vækst i maritime sektor. Nordjyske,14. december.

Jørgensen, H. (2002). Consensus, Cooperation and Conflict: The Policy Making Process in Denmark. Cheltenham, UK: Edward Elgar.

Jørgensen, H. (2006). Arbejdsmarkedspolitikkens fornyelse - innovation eller trussel mod dansk flexicurity?. København: LO \& FTF.

Jørgensen, H. (2009). From a Beautiful Swan to an Ugly Duckling: the Renewal of Danish Activation Policy Since 2003. European Journal of Social Security, 11(4), 337-367. https://doi. org/10.1177/138826270901100401

Jørgensen, H \& Jørgensen, H. H. B. (2016). Arbejdsmarkedspolitikkens endeligt. Altinget.dk, 5. oktober. https://www.altinget.dk/arbejdsmarked/artikel/debattoerer-hvad-betyder-regeringens-farve-for-arbejdsmarkedspolitik.

Jørgensen, H., Baadsgaard, K. \& Klindt, M. P. (2017). Beyond flexicurity: the shift towards work-first and its implications for street-level work in the Danish employment system. I 
Høgsbro, K. \& Shaw, I. (red.), Social Work and Research in Advanced Welfare States (s. 47-60). London: Routledge.

Kvist, J. \& Harsløf, I. (2014). Workfare with Welfare Revisited: Instigating Dual Tracks for Insiders and Outsiders. I Lødemel, I. and Moreira, A. (red.) Activation or Workfare? Governance and the Neo-liberal Convergence (). New York, NY: Oxford University Press.

Kvist, J. \& Pedersen, L. (2007). Danish Labour Market Activation Policies. National Institute Economic Review, 202, 99-112. https://doi. org/10.1177/0027950107086172

Larsen, C. A. \& Andersen J. G. (2005). Magten på Borgen. En analyse af beslutningsprocesser i større politiske reformer. Magtudredningen. Aarhus: Aarhus Universitetsforlag.

Larsen, F. (2011). Kommunal beskaftigelsespolitik: Kommunale jobcentre mellem statslig styring og kommunale autonomi. København: Frydenlund Academic.

Larsen, F. (2013). Active Labour Market Reform in Denmark: The Role of Governance in Policy Change. I Brodkin, E. Z. \& Marston, G. (red.), Work and the Welfare State: Street-Level Organizations and Workfare Politics. Washington, D.C: Georgetown University Press.

M-ploy (2017). Analyse af reglerne om statens refusion. Analyse udført for KL og Styrelsen for Arbejdsmarked og Rekruttering (STAR).

Madsen, P. K. (2005). The Danish Road to Flexicurity: Where are we? And how did we get there?. I Bredgaard, T. \& Larsen, F. (red.), Employment policy from different angels (s. 269-289). København: DJØF Publishing.

Mahoney, J. \& Thelen, K. (2010). A Theory of Gradual Institutional Change. I Mahoney, J. \& Thelen, K. (red.), Explaining Institutional Change: Ambiguity, Agency, and Power (s. 1-37). New York, NY: Cambridge University Press.

Munch, J. R. \& Skipper, L. (2008). Program Participation, Labor Force Dynamics, and Accepted Wage Rates. I Fomby, T., Hill, R. C., Millimet, D. L., Smith, J. A. \& Vytlacil, E. J. (red.), Modelling and Evaluating Treatment Effects in Econometrics (s. 197-262). West Yorkshire, UK: Emerald Publishing.
Nørgaard, A. S. (2009). Kommunalisering af det offentlige ansvar for arbejdsløshedsforsikring: Mellem incitamenter og social sikring. Samfundsøkonomen, 5, 37-43.

Peck, J. and Theodore N. (2001). Exporting workfare/importing welfare-to-work: exploring the politics of third way policy transfer. Political Geography, 20(4), 427-460.

Peters, G. (1999). Institutional Theory in Political Science: The 'New Institutionalism'. New York, NY: Continuum.

Regeringen (Socialdemokraterne og Det Radikale Venstre) \& Venstre, Dansk Folkeparti \& Det Konservative Folkeparti (2014). Forlig om reform af beskaeftigelsesindsatsen.

Regeringen (Venstre, Det Konservative Folkeparti \& Liberal Alliance) \& Dansk Folkeparti (2018). Aftale om forenkling af erhvervsfremmesystemet.

Rosholm, M. \& Svarrer, M. (2004). Estimating the Threat Effect of Active Labour Market Programmes. IZA Discussion Paper No. 1300. http://ftp.iza.org/dp1300.pdf

Rosdahl, A. \& Weise, H. (2000). When all must be active - workfare in Denmark. I Lødemel, I. \& Trickey, H. (red.), An Offer You Can't Refuse' Workfare in International Perspective (s. 159-180). Bristol, UK: The Policy Press.

Streeck, W. \& Thelen, K. (2005). Introduction: Institutional Change in Advanced Political Economies. I Streeck, W. \& Thelen, K. (red.), Beyond Continuity: Institutional Change in Advanced Political Economies (s. 1-39). New York, NY: Oxford University Press.

Sørensen, E. \& Torfing, J. (2011). Offentlig styring som metastyring. I Damgaard, B. \& Sørensen, E. (red.), Styr på beskaeftigelsespolitikken (s. 35-54). Købehavn: Jurist- og Økonomforbundets Forlag.

Thelen, K. (2010). Beyond Comparative Statics: Historical Institutional Approaches to Stability and Change in the Political Economy of Labor. I Morgan, G., Campbell J. L, Crouch, C., Pedersen, O. K, \& Whitley, R. (red.), The Oxford Handbook of Comparative Institutional Analysis (s. 41-61). New York, NY: Oxford University Press. https://dx.doi.org/10.1093/ oxfordhb/9780199233762.003.0003. 
Thelen, K. (2014). Varieties of liberalization and the new politics of social solidarity. New York: Cambridge University Press.

Torfing, J. (2004). Det stille sporskifte i velfoerdsstaten. En diskursteoretisk beslutningsprocesanalyse. Magtudredningen. Aarhus: Aarhus Universitetsforlag.

Torfing, J. (2005). Institutionelle teorier inden for politologi. I Nielsen, K. (red.), Institutionel

\section{Noter}

1. Beskæftigelsesministeriets har en hel database (www.jobeffekter.dk) over forskning, der undersøger effekter af arbejdsmarkedspolitiske indsatser.

2. Som led i aftalen mellem Regeringen og Dansk Folkeparti om en forenkling af erhvervsfremmesystemet blev det i foråret teori-en tvoerfaglig introduktion (s. 45-64). Frederiksberg: Roskilde Universitetsforlag.

Villumsen, S.G.K. \& Vilhelmsen, J. (2017). Markant fald $i$ aktiveringen af dagpengemodtagere. Analyse af AE-rådet og Danske A-kasser.

Winther, M. B. \& Svendsen, G. L. H. (2012). 'The Rotten Banana' fires back: The story of a Danish discourse of inclusive rurality in the making. Journal of Rural Studies, (28), 466-477. https://doi.org/10.1016/j.jrurstud.2012.05.003

2018 besluttet, at Regionerne fra 1.1.2019 afskæres fra at kunne føre en selvstændig turisme- og erhvervsfremmeindsats. Som led i aftalen overgår administrationen af EU's strukturfonde til en ny national erhvervsfremmebestyrelse (Regeringen og Dansk Folkeparti, 2018).

\section{BILAG 1}

Kommunernes brug af ordinær uddannelse i beskæftigelsesindsatsen. Tabellen angiver, hvor stor en procentandel af kommunens aktiverede dagpengemodtagere, der har fået ordinær uddannelse som led i deres aktivering. Tal er fra 2016.

\begin{tabular}{llll}
\hline Gladsaxe & 2.9 & Fredensborg & 16.7 \\
\hline Herlev & 3.0 & Billund & 16.7 \\
\hline Frederiksberg & 4.2 & Vallensbæk & 16.9 \\
\hline Glostrup & 4.2 & Mariagerfjord & 16.9 \\
\hline Lyngby-Taarbæk & 5.2 & Rødovre & 17.0 \\
\hline Solrød & 5.5 & Stevns & 17.2 \\
\hline Hørsholm & 6.1 & Helsingør & 17.2 \\
\hline Vordingborg & 6.6 & Odense & 17.5 \\
\hline Næstved & 6.9 & Ishøj & 17.5 \\
\hline
\end{tabular}

Fortsaettes på noeste side... 


\begin{tabular}{|c|c|c|c|}
\hline Rudersdal & 7.0 & Esbjerg & 17.8 \\
\hline Syddjurs & 7.6 & Favrskov & 18.3 \\
\hline Allerød & 8.0 & Vejle & 18.6 \\
\hline Holbæk & 8.4 & Tårnby & 19.3 \\
\hline Gribskov & 8.7 & Silkeborg & 19.4 \\
\hline Gentofte & 8.9 & Faxe & 19.6 \\
\hline Lejre & 9.1 & Skive & 20.6 \\
\hline Kerteminde & 9.4 & Hillerød & 20.8 \\
\hline Ballerup & 9.7 & Lolland & 21.9 \\
\hline Dragør & 10.0 & Hvidovre & 22.1 \\
\hline Frederikssund & 10.2 & Sønderborg & 23.5 \\
\hline Guldborgsund & 10.4 & Bornholm & 24.1 \\
\hline Aarhus & 11.0 & Svendborg & 24.1 \\
\hline Halsnæs & 11.0 & Brøndby & 25.0 \\
\hline Rebild & 11.2 & Middelfart & 25.0 \\
\hline København & 11.6 & Kolding & 25.7 \\
\hline Varde & 11.9 & Roskilde & 26.4 \\
\hline Kalundborg & 12.6 & Struer & 26.5 \\
\hline Køge & 12.6 & Brønderslev & 28.2 \\
\hline Odder & 12.6 & Assens & 28.2 \\
\hline Nordfyns & 13.2 & Odsherred & 28.3 \\
\hline Nyborg & 13.4 & Tønder & 28.6 \\
\hline Greve & 13.5 & Langeland & 28.7 \\
\hline Ringsted & 13.7 & Albertslund & 29.6 \\
\hline Morsø & 13.8 & Vesthimmerland & 30.2 \\
\hline Randers & 14.1 & Haderslev & 30.9 \\
\hline Furesø & 14.1 & Ikast-Brande & 31.0 \\
\hline
\end{tabular}




\begin{tabular}{llll}
\hline Herning & 14.6 & Aalborg & 31.1 \\
\hline Vejen & 14.8 & Holstebro & 33.1 \\
\hline Hedensted & 15.2 & Horsens & 33.2 \\
\hline Høje-Tåstrup & 15.4 & Faaborg-Midtfyn & 34.5 \\
\hline Norddjurs & 15.5 & Jammerbugt & 34.7 \\
\hline Viborg & 15.5 & Ringkøbing-Skjern & 35.6 \\
\hline Aabenraa & 15.7 & Thisted & 36.2 \\
\hline Egedal & 16.1 & Fredericia & 37.9 \\
\hline Slagelse & 16.3 & Lemvig & 39.3 \\
\hline Sorø & 16.3 & Frederikshavn & 40.3 \\
\hline Skanderborg & 16.6 & Hjørring & 51.8 \\
\hline
\end{tabular}

Kilde: $w w w . j o b i n d s a t s . d k$

Mads Peter Klindt, lektor, CARMA (Center for Arbejdsmarkedsforskning), Institut for Statskundskab, Aalborg Universitet e-mailmpk@dps.aau.dk

Rasmus Ravn, ph.d.-studerende, CARMA (Center for Arbejdsmarkedsforskning), Institut for Statskundskab, Aalborg Universitet e-mail rr@dps.aau.dk 